Article

\title{
Impact of Entrepreneurial Self-Efficacy and Entrepreneurial Motivation on Micro and Small Business Success for Food and Beverage Sector in East Java, Indonesia
}

\author{
Veronika Agustini Srimulyani $^{1}$ (D) and Yustinus Budi Hermanto ${ }^{2, *(D)}$ \\ 1 Management Program Study, Widya Mandala Catholic University, Surabaya 60112, East Java, Indonesia; \\ sveronikaagustinis@gmail.com \\ 2 Management Study Program, Darma Cendika Catholic University, Surabaya 60117, East Java, Indonesia \\ * Correspondence: yustinus.budi@ukdc.ac.id
}

Citation: Srimulyani, Veronika Agustini, and Yustinus Budi

Hermanto. 2022. Impact of

Entrepreneurial Self-Efficacy and Entrepreneurial Motivation on Micro and Small Business Success for Food and Beverage Sector in East Java, Indonesia. Economies 10: 10. https://doi.org/10.3390/ economies10010010

Academic Editors: Alexey Mikhaylov and Franklin G. Mixon

Received: 31 October 2021

Accepted: 24 December 2021

Published: 30 December 2021

Publisher's Note: MDPI stays neutral with regard to jurisdictional claims in published maps and institutional affiliations.

Copyright: (C) 2021 by the authors. Licensee MDPI, Basel, Switzerland. This article is an open access article distributed under the terms and conditions of the Creative Commons Attribution (CC BY) license (https:// creativecommons.org/licenses/by/ $4.0 /)$.

\begin{abstract}
The research aims to examine the impact of entrepreneurial self-efficacy and entrepreneurial motivation on the success of the food and beverage (F\&B) sector's micro and small enterprises (MSEs). The sample was selected using purposive sampling techniques from 267 MSE owners in the F\&B businesses in Madiun City, Madiun Regency, and Magetan Regency, East Java, Indonesia. The test results of the hypothesis showed that: (1) partially, self-efficacy entrepreneurship and entrepreneurial motivation are significantly positive on business success in micro and small F\&B businesses in East Java, Indonesia; (2) entrepreneurial motivation acts as a partial mediation of the influence of selfefficacy entrepreneurship on the business success of micro and small businesses in the field of food and beverage in East Java, Indonesia; abd (3) simultaneously, self-efficacy entrepreneurship and the influence of entrepreneurial motivation are significantly positive on business success in micro and small businesses in the food and beverage fields of East Java, Indonesia. The results showed that self-efficacy and motivation in entrepreneurship are necessary because they affect business success, particularly in micro and small F\&B businesses in Indonesia. Further research can explore other factors that influence business success by expanding the research area and other types of creative industry businesses. Further research could explore other factors influencing business success by expanding research areas, such as entrepreneurial leadership and innovative work behavior.
\end{abstract}

Keywords: entrepreneurial self-efficacy; entrepreneurial motivation; business success; food and beverage

\section{Introduction}

Entrepreneurial empowerment is closely related to improving life and welfare for regional development by exploring entrepreneurs' strategic potential. The result of entrepreneurship in various countries has made much progress, especially in Indonesia (Oetomo and Utami 2019). Various previous studies have noted that micro, small and medium enterprises (MSMEs) play an essential role in a country's economy so that the performance of the MSME sector is closely related to the performance of the nation (Chittithaworn et al. 2011); in addition, the potential and role of entrepreneurship has proven to be resistant to various crises. Micro, small, and medium enterprises (MSMEs) in Indonesia play a role in creating job opportunities for $96.87 \%$ of the workforce in Indonesia and have an important position in the sustainability of the Indonesian economy (Republika 2019). The realization of the contribution of MSMEs to the national Gross Domestic Product (GDP) in 2018 reached around 60.34\%, and the estimated contribution of MSMEs to GDP increased by 5\% in 2019 (Syarizka 2019). The food and beverage (F\&B) industry are able to make a significant contribution to the national economy. Throughout 2020, the food and beverage industry, which is a subsector of the non-oil and gas processing industry, became the largest contributor to national GDP, reaching $7.02 \%$, and the food and beverage industry 
also provided the highest export value in the manufacturing group, which penetrated IDR 27.59 billion in January-November 2020 (Ramdhani 2021).

In the time of the COVID-19 pandemic, many MSEs in Indonesia are struggling to deal with their business; more than a few have gone out of business. However, the growth of the healthy food and beverage culinary business continues to rise due to public awareness of a healthy lifestyle. One of the business opportunities in question is the ready-to-eat processed food business. The situation of social restrictions during the COVID-19 pandemic caused people, especially millennials, to get used to buying frozen or ready-to-cook food because it is easier and more efficient in terms of serving. One of the business strategies to maintain food and beverage (F\&B) businesses in the era of the COVID-19 pandemic is to take advantage of opportunities in the digital ecosystem. In the framework of national economic recovery, MSMEs can restore the creative economy to passion, especially in the culinary sector. This is because food and beverage $(F \& B)$ are the primary requirements. Likewise, micro and small group entrepreneurs in the food and beverage sector in Madiun City were chosen as a study because this field continues to increase in number, and many of these business actors continue to operate during the COVID-19 pandemic with the MSME movement going online as an opportunity for business actors to improve their business. The development of the entrepreneurial community in Madiun City is relatively rapid. This is indicated by the number of MSMEs in Madiun City.

The growth of MSMEs in Madiun City, East Java, has been significant in the past year; namely, there are 23,000 MSME actors developing micro, small, and medium enterprises spread across 27 Kelurahan in 23 Districts, namely, Kartoharjo, Taman, and Manguharjo engaged in various fields such as convection, services, food, drinks, crafts, trade, and more (Harianto 2020, https: / / news.detik.com/ accessed on 14 October 2021). The culinary industry in Madiun City and Madiun Regency is growing rapidly enough to become superior in the form of culinary tourism for foods such as pecel rice (https: / / warung-nasipecel-yu-gembrot.business.site/ accessed on 30 October 2021), jotos rice (https: / Www. cakwicak.com/2021/06/nasi-jotos-madiun.html accessed on 30 October 2021), lontong tofu telor (https://superapp.id/blog/lifestyle/makanan-khas-madiun accessed on 30 October 2021), corah pentol, cokro bluder (https:/ / www.cokrogroup.com accessed on 30 October 2021), brem (https: / / www.timesindonesia.co.id/read/news/337677/ accessed on 30 October 2021), manco cake, madu mongso (https://new.detik.com/ accessed on 30 October 2021), and tempeh (https:/ / www.timesindonesia.co.id/read/news/339226/ accessed on 30 October 2021). The rapid development of MSEs in the culinary field is evidenced by the increasing number of business actors who build cafes, coffee shops, and restaurants in the City and Madiun Regency areas. As a tourist destination, the food and beverage business sector is the third contributor, with economic growth reaching 7.47 percent in the city of Madiun (Harianto 2020, https://news.detik.com/ accessed on 14 October 2021). The Madiun City Government has provided adequate marketing places such as the Sunday Market at the Traffic Park Bantaran Kali Madiun. Since mid-2019 and in 2020, the government began to develop culinary centers and art alleys. This program is specifically designed to accommodate MSME products in one place to make them easily accessible to the public.

On the culinary side, Indonesian food and drink is part of the best wealth legacy in the world; therefore, culinary tourism is one of the attractions in various regions in Indonesia. In addition to the Madiun area, the Magetan regency area also has culinary tours that are the flagship of the local government, featuring foods such as: Gandu roast chicken (https:/ / visit.magetan.go.id/2021/09/22/ayam-panggang-gandu-bu-setu on accessed on 30 October 2021), sponge cake (https: / regional.kompas.com/read/2019/01/14/12253671/ accessed on 30 October 2021), tempeh chips, yam chips, corn rice, pecel rice (https:// www.tripadvisor.co.id/restaurant_review-Warung Nasi Pecel Bu Parti, Magetan-Ulasan Restoran-Tripadvisor/ accessed on 30 October 2021), and traditional herbs, as well as traditional "gethuk" foods (https:/ / www.facebook.com-gethuk-bakar-abimanyu-cabangmagetan/accessed on 30 October 2021); (https:/ /www.gotravelly.com/cullinary-Getuk 
Pisang Diana Magetan/accessed on 30 October 2021). Culinary tourism is predicted to continue to grow, although the COVID-19 pandemic still exists.

Economic growth is an important development that must be owned by a region, where stable economic growth will lead to prosperity in an area. Entrepreneurs create jobs and contribute to productivity and growth (Van Praag and Versloot 2008; McLarty et al. 2012; Simpson et al. 2012; and Garaika and Margahana 2019). The success of a business is undoubtedly influenced by many factors, both internal and external factors. Examples of external factors are stable economic growth and good social conditions. In contrast, internal factors are the influence of parents, one's ability to manage a business unit (self-efficacy), personality, courage to take risks, and motivation to achieve goals (Santoso and Oetomo 2018). Shakeel et al. (2020) show that entrepreneurs' characteristics, external business environments, and supportive factors are positively related to the performance of women-owned businesses. This is supported by Caliendo et al. (2010), which states that the determinants of entrepreneurial persistence are the individual characteristics of entrepreneurs in the form of human capital, personality traits, and business characteristics. These personal characteristics strengthen the findings of Chen et al. (1998). They state that business founders (entrepreneurs) have higher self-efficacy (SE) in innovation and risk-taking entrepreneurial roles and tasks, such as marketing, innovation, management, risk-taking, and financial control, than non-business founders.

Sweida and Reichard (2013) define SE as a personal estimate of an individual's cognitive and physical ability to exercise control over situational demands. In general, entrepreneurial self-efficacy (ESE) is defined as the strength of an individual's belief that they can successfully perform various entrepreneurial roles and tasks (Chen et al. 1998). Garaika and Margahana (2019) show that internal factors such as self-efficacy, self-personality, and self-confidence, and external factors such as education and role models affect entrepreneurial intention for young entrepreneurs. Wardana et al. (2020) show that entrepreneurship education has influenced entrepreneurial self-efficacy, entrepreneurial attitude, and mindset. SE has a significant positive impact on entrepreneurial behavior (Shaheen and AL-Haddad 2018); increasing business success by encouraging one's performance in various fields, including the business sector (Budiman and Pangestu 2018; Ngek 2015; and Oyeku et al. 2020) and the business performance of women entrepreneurs (Yusuff et al. 2019); and influencing entrepreneurial motivation (Santoso and Oetomo 2018; Nuryanto et al. 2019) and mediating the effect of self-efficacy on entrepreneurial intention (Kristiadi et al. 2016). From these various empirical studies, it can be concluded that selfefficacy is very important for business actors to have in running a business in order to ensure that the company they are undertaking can achieve success.

Another factor that influences entrepreneurial success is entrepreneurship motivation (EM). EM can influence entrepreneurial intentions and decisions to start a business (Kristiadi et al. 2016; Santoso and Oetomo 2018; and Barba-Sánchez and Atienza-Sahuquillo 2012) and affect the innovation process and business performance and success (Machmud 2017; and Budiman and Pangestu 2018). Hartman and Herb (2015) mention that motivation and success are considered essential entrepreneurship components. Motivation is a stimulus that encourages individuals to act to achieve specific goals. Self-motivation that leads to entrepreneurial activity is defined as a stimulus that can enable individuals to do business and be carried out with enthusiasm, creativity, innovation, and the courage to take risks to get profits, either in the form of money or other benefits (Santoso and Oetomo 2018). Kisker (2016) proves that four motivational factors (independence, need for achievement, social recognition, and financial rewards) positively and significantly affect survival success.

Islam et al. (2020) conducted a study on 133 small and medium-sized businesses in the food sector in the Kazakh city of Almaty. They found a significant relationship between the self-efficacy of entrepreneurship, entrepreneurial resilience, and the financial performance of MSEs. The results of Kimathi et al.'s (2019) research on MSEs in Kenya show that ESE is a good predictor of high business performance. The results of a study by Khalil et al. (2021) on 353 small businesses in Pakistan showed that the dimensions of ESE significantly 
affected small business performance. Ummah and Gunapalan (2012) conducted research on women entrepreneurs operating at small scales in Sri Lanka, showing that achievement, autonomy, and confidence are the most important factors for business success. Chu et al. (2011) explained that the motivation of business ownership of entrepreneurs in Beijing, Shanghai, and Guangzho is to increase revenue, become their own boss, and prove that they can succeed for the most important reasons. Reputation for honesty, providing good customer service and having good management skills become the necessary conditions for business success, and customer friendliness and hard work are also important for high-performing companies. Table 1 shows the summary of previous research studies and current research.

Table 1. Summary of Previous Research Studies and Current Research.

\begin{tabular}{llll}
\hline $\begin{array}{l}\text { Name of Researcher } \\
\text { (Year) }\end{array}$ & Research Variables & Research Area & Research Objects \\
\hline & & & \\
& & & \\
Chu et al. (2011) & $\begin{array}{l}\text { Motivation of Business } \\
\text { ewnership of }\end{array}$ & $\begin{array}{l}\text { Beijing, Shanghai, } \\
\text { and Guangzho, China }\end{array}$ & Snall and Medium \\
\end{tabular}

\section{Research Results}

Motivation of business ownership of entrepreneurs in Beijing, Shanghai, and Guangzho is to increase revenue, become their own boss, and to prove that they can succeed the most important reason; reputation for honesty, providing good customer service, and having good management skills become the necessary conditions for business success, and customer friendliness and hard work are also important for high-performing companies.

\begin{tabular}{|c|c|c|c|c|}
\hline $\begin{array}{l}\text { Ummah and } \\
\text { Gunapalan (2012) }\end{array}$ & $\begin{array}{ll}\text { - } & \text { Achievement } \\
\text { - } & \text { Autonomy } \\
\text { - } & \text { Confidence } \\
\text { Business success }\end{array}$ & Sri Lanka & $\begin{array}{l}\text { Small Woman } \\
\text { Entrepreneurs }\end{array}$ & $\begin{array}{l}\text { Achievement, autonomy, and } \\
\text { confidence are the most } \\
\text { important factors for business } \\
\text { success. }\end{array}$ \\
\hline Kimathi et al. (2019) & $\begin{array}{ll} & \text { ESE } \\
- & \text { Business } \\
& \text { performance }\end{array}$ & Kenya & $\begin{array}{l}\text { Micro, Small } \\
\text { Entrepreneurs }\end{array}$ & $\begin{array}{l}\text { ESE is a good predictor of high } \\
\text { business performance }\end{array}$ \\
\hline Islam et al. (2020) & $\begin{array}{ll}\text { - } & \text { ESE } \\
\text { - } & \text { entrepreneurial } \\
& \text { resilience } \\
\text { - } & \text { financial } \\
& \text { performance }\end{array}$ & Kazakh City, Almaty & $\begin{array}{l}\text { Small and Medium } \\
\text { Businesses }\end{array}$ & $\begin{array}{l}\text { There is a significant } \\
\text { correlation between } \\
\text { entrepreneurial self-efficacy, } \\
\text { entrepreneurial resilience, and } \\
\text { the financial performance of } \\
\text { SMEs. }\end{array}$ \\
\hline Khalil et al. (2021) & $\begin{array}{l}\text { Dimensions of } \\
\text { Entrepreneurial } \\
\text { Self-Efficacy (ESE) }\end{array}$ & Pakistan & $\begin{array}{l}\text { Small businesses in } \\
\text { the food sectors }\end{array}$ & $\begin{array}{l}\text { There is a significant influence } \\
\text { on the dimension of ESE on } \\
\text { small business performance }\end{array}$ \\
\hline This study & $\begin{array}{ll}- & \text { ESE } \\
- & \text { Entrepreneurial } \\
& \text { Motivation (EM) } \\
- & \text { Business success } \\
& (\mathrm{BS})\end{array}$ & $\begin{array}{l}\text { Madiun, Magetan, } \\
\text { East Java, Indonesia }\end{array}$ & $\begin{array}{l}\text { Micro, Small } \\
\text { Entrepreneurs in } \\
\text { the food \& } \\
\text { beverage sectors }\end{array}$ & $\begin{array}{l}\text { ESE and EM significantly and } \\
\text { positively affect business } \\
\text { success, both simultaneously } \\
\text { and partially. The results also } \\
\text { showed that EM mediated the } \\
\text { influence of ESE on BS. }\end{array}$ \\
\hline
\end{tabular}

MSE owners who are also leaders have a significant contribution and role in the progress of MSMEs. The existence of self-efficacy and the strong desire of business owners 
to develop a business and have the drive to run a business successfully is an ideal that an owner expects. Self-efficacy and entrepreneurial motivations are the main components of entrepreneurial values in improving employee performance and business performance. Business performance will increase along with applying entrepreneurial values for MSE owners. The sustainability of MSMEs will depend on the performance of MSEs that have been achieved. MSMEs play a vital role in the development of the economy. Based on data from the Ministry of Tourism and Creative Economy (kemparekraf), culinary subsectors in Indonesia accounted for IDR 455.44 trillion, or about $41 \%$ of the total creative gross domestic product (GDP), which totaled IDR 1134.9 trillion in 2020; in addition, culinary subsectors also absorb the most labor, namely, 9.5 million people (Situmorang 2021). This means that culinary subsectors are the largest contributor to the Gross Domestic Product of the creative economy. In this context, the research aims to analyze entrepreneurial selfefficacy's direct and indirect effects on entrepreneurial motivation by examining research on food and beverage MSEs in Madiun City, Madiun Regency, and Magetan Regency, East Java, Indonesia.

The difference between this study and previous studies (Shakeel et al. 2020; Caliendo et al. 2010; Oyeku et al. 2020; and Santoso and Oetomo 2018) lies in the focus of research studies on two entrepreneurial characteristics factors in achieving business success in the food and beverage sectors in Madiun city, Madiun Regency, and Magetan Regency, East Java, namely, entrepreneurial self-efficacy (ESE) and entrepreneurial motivation (EM). These two factors were reviewed because they separately influenced entrepreneurial intentions and business performance in several previous studies. MSEs have a vital role in developing the economy, and analyzing ESE and EM can benefit entrepreneurs operating in micro and small businesses. Improving ESE and EM can contribute to helping entrepreneurs operate better, eventually leading to improved performance. Moreover, this study can provide a better understanding to other stakeholders, specifically governments, who can develop better policies to facilitate small businesses in improving ESE and EM to compete in this dynamic industry. Our research assumes that both ESE and EM can influence both partially and simultaneously against BS by conducting research on small micro-businesses in the food and beverage sectors. The study also examined the effect of EM mediation on the influence of ESE on BS.

The research questions were developed as follows: (1) does ESE have a significant positive influence on business success? (2) does EM have a significant positive influence on business success?; (3) does ESE indirectly influence business success through EM as a mediator?; and (4) do ESE and EM simultaneously significantly influence business success?

\section{Theoretical Review}

\subsection{Business Success (BS)}

The main goal of entrepreneurs running a business is business success so that all activities are shown to achieve success. In business studies, the concept of success is often used to refer to a firm's financial performance (Chittithaworn et al. 2011). However, there is no generally accepted definition of success, and business success has been interpreted in many ways (Foley and Green 1989). Business success can be interpreted as a state of increasing progress of a business, seen from business capacity, net assets, and net income. Oyeku et al. (2020) show that an increase in entrepreneurial orientation, entrepreneurial selfefficacy, and environmental uncertainty causes entrepreneurial success seen from financial and non-financial aspects, which include: profitability, market share, net asset growth, sales growth, and government policies. From some of these expert opinions, it can be concluded that business success can be interpreted as a state of increasing business progress, viewed from financial and non-financial aspects.

Nunes et al. (2012) studied MSEs performance indicators covering various aspects: financial, market and customers, processes, human resources, and other factors such as supplier services, legal environment, and social programs. Chittithaworn et al. (2011) show that the characteristics of SMEs, customers, and markets, ways of doing business, resources, 
and finances, and the external environment significantly influence business success. A growing business is the hope of everyone who starts a business, but it does not happen instantly (Adolfina and Lumintang 2018). There is no consensus among researchers on the factors that contribute to business success, but some variables were discussed more often in previous studies which are grouped into the following categories: (1) related to psychology and the behavioral characteristics of entrepreneurs; (2) managerial skills and training employers; and (3) the external environment in which entrepreneurs operate. From the various empirical studies of external factors that influence the success of a company, including the family environment, task environment, aspects of government policy in the SMEs sector, elements of roles related to institutions, social aspects, cultural aspects, and economic aspects (Rachmania et al. 2012), it is no less important to note the factor of internal resources, known as the resource-based view (RBV). RBV is divided into three types, namely, (1) physical resources which include factories, equipment, location, technology, raw materials, and machines; (2) human resources including employees, training, experience, intelligence, knowledge, expertise, and competence; and (3) organizational resources including organizational structures, planning processes, information systems, patents, trademarks, copyrights, data centers, and so on (David and David 2017).

\subsection{Entrepreneurial Self-Efficacy (ESE)}

Self-efficacy (SE) has been defined by researchers from various perspectives. According to Bandura (1977), SE is defined as an individual's confidence about one's abilities to accomplish a specific task or achieve individual goals, while according to Sweida and Reichard (2013), SE is a personal estimate of an individual's cognitive and physical ability to exercise control over situational demands. Generally, the concept of self-efficacy comes from the psychological construct of social cognitive theory (SCT), which explains people's beliefs in their ability to influence their actions and produce the desired results. SE relates to a person's ability to perform a task. SE relates to one's belief in one's ability to perform tasks, achieve goals, and overcome obstacles. According to Wood and Bandura (1989), SE is related to individual perceptions of the skills possessed in completing tasks. According to Prodan and Drnovsek (2010) SE is the most influential factor in explaining entrepreneurial interest that will encourage action. The concept of self-efficacy includes three dimensions: magnitude, strength, and generality (Ivancevich et al. 2005). Definition of ESE focuses on the need for entrepreneurs to develop beliefs to control negative thinking (Drnovšek et al. 2010). The magnitude dimension measures the difficulty of the task that is believed to be completed; the strength dimension identifies whether seriousness is high and if they can produce persistence in the face of adversity, and the dimension of generality assesses a person's ability to apply wisdom in different situations.

Luthans (2011) explains that SE is an individual's belief in their ability to mobilize the motivation, cognitive resources, and actions needed to perform specific tasks. When SE is associated with business people, it leads to confidence in completing business goals related to uncertainty in the future. Uncertainty about the results obtained requires confidence and specific competencies related to improving business performance. Learning makes a person able to develop knowledge, skills, and positive behavior. Learning outcomes can generate creative power by creating new processes in business (Gibson et al. 2012) so that effectiveness and efficiency can be achieved and improve business performance and independence. Academics argue that self-efficacy is a good thing for entrepreneurs to have. For example, scholars such as Shane et al. (2003) argue that an entrepreneur who is high in self-efficacy tends to "exert more effort for a larger period of time, persevere through setbacks, and develop better plans and strategies for the task being executed. Ngek (2015); Budiman and Pangestu (2018); Islam et al. (2020); and Khalil et al. (2021) prove entrepreneurial self-efficacy's positive and significant influence on business success. Entrepreneurial self-efficacy significantly affects entrepreneurial intention (Martyajuarlinda and Kusumajanto 2018; Lamanepa and Sidharta 2019; and Garaika and Margahana 2019) and entrepreneurial decisions (Sitinjak 2019), while Adolfina and Lumintang (2018) prove 
that motivation to start a business and self-efficacy has a significant effect on developing a business. Zaini et al. (2016) showed that self-efficacy and family factors positively influence women's entrepreneurial intention.

Meanwhile, entrepreneurial self-efficacy research is based on social cognitive theory and planned behavior theory (Ajzen 1991), which explains the emergence of entrepreneurial intentions and entrepreneurial actions such as business creation and growth. Based on the idea of planned behavior, ESE indicates the extent to which an individual's perceived behavioral control is the primary determinant of an individual's intention to engage in a particular behavior (Krueger et al. 2000). ESE is the self-confidence individuals have to succeed in carrying out specific task roles in entrepreneurship.

The higher the ESE possessed by an entrepreneur, the higher the success of the business undertaken. Entrepreneurs have the confidence and trust to carry out entrepreneurial tasks, including dealing with their business environment's dynamic conditions. We speculate that entrepreneurship self-efficacy will be needed for SMEs to manage crises such as COVID-19 in order to survive successfully.

Hypothesis 1 (H1). Entrepreneurial self-efficacy (ESE) has a significant positive effect on business success.

\subsection{Entrepreneurial Motivational (EM)}

"Motivation" comes from the Latin "move", which means to move. Motivation for business actors is an internal factor contained in entrepreneurship. Internal factors are the most dominant factors affecting the business performance of MSEs, such as the availability of resources, personal skills, entrepreneurial abilities, and the ability to use internal resources effectively. According to Huarng et al. (2012), EM is a strong urge from within a person to actualize one's potential through creative and innovative thinking in creating new products and having added value for many parties. Empirical studies Gemina et al. (2016) showed that business motivation, directly and indirectly, affects business success with business ability as a mediation, while Ardiyanti and Mora (2019) found that business interest and business motivation simultaneously significantly influence the business success of young entrepreneurs. Eijdenberg et al. (2015) prove that strong predictors of small business growth are: (1) motivation related to family background, opportunities, and needs and (2) motivation related to opportunities. The results of the study are in line with Amit and MullerAmit (1995), who argue that "when both forces ("pull" and "push") are at work, one might expect superior performance".

Kisker (2016) examines the impact of motivational factors consisting of independence, need for achievement, social recognition, and financial rewards, which have been shown to have a positive and significant effect on the survival success of a business, while Muthalib and Yulianti (2015), Machmud (2017), and Budiman and Pangestu (2018) show that EM has a significant effect on both the innovation process and business performance. These motivational factors are the cause of one's satisfaction. This satisfaction will increase the enthusiasm to carry out business activities so that it affects the success of the business undertaken. This means that self-motivation for entrepreneurship can affect business success; with solid motivation, business actors have a high self-motivation to be persistent and have a factual determination to run a business and achieve success.

Hypothesis 2 (H2). Entrepreneurial motivation (EM) has a significant positive effect on business success.

Entrepreneurial belief in self-ability in entrepreneurial tasks can be a solid self-motivation to build, promote, and maintain their business in any situation. The existence of solid self-motivation will encourage entrepreneurs to do the best for their business so that the business carried out has maximum results. In another study (Santoso and Oetomo 2018; and Nuryanto et al. 2019) found a significant effect of self-efficacy on entrepreneurial motiva- 
tion. Furthermore, in another study, reason acts as a mediating influence of self-efficacy on entrepreneurial intention (Kristiadi et al. 2016), and entrepreneurial achievements (Eliyana et al. 2020) and entrepreneurial intention are strong predictors of one's actions to start a new business (Bernardus et al. 2020). Lampadarios (2017) identified that entrepreneurial orientation is an antecedent of business growth, has a significant favorable influence on business performance, and becomes a competitive advantage for MSEs. Entrepreneurs with high self-efficacy believe in their ability to achieve the set business targets, thereby increasing strong motivation in entrepreneurship to affect one's business success.

Hypothesis 3 (H3). Entrepreneurial motivational (EM) mediator influences entrepreneurial self-efficacy (ESE) on business success.

To improve self-competence and EM, entrepreneurs require an enterprising spirit to progress and be successful. ESE and EM influence entrepreneurial intentions and decisions to start a business (Santoso and Oetomo 2018). The performance or achievements achieved by entrepreneurs are obtained through confidence in their abilities in carrying out entrepreneurial activities such as creativity and innovation in generating new ideas or products and marketing products produced by an entrepreneur who has a strong motivation in entrepreneurship, such as independence-the need for achievement, social recognition, and income. ESE is beneficial for entrepreneurs because it motivates them to improve self-competence, and EM is a driving spirit for entrepreneurs to succeed. Entrepreneurs to improve self-competence and EM is an enterprising spirit for entrepreneurs to progress and be successful. ESE and EM influence entrepreneurial intentions and decisions to start a business (Santoso and Oetomo 2018).

Hypothesis 4 (H4). Simultaneously, entrepreneurial self-efficacy (ESE) and entrepreneurial motivational (EM) significantly influence business success.

\section{Materials and Methods}

\subsection{Research Design}

The first phase of research was conducted in early 2020 by taking the research area in Madiun City and Madiun Regency with the population of food and beverage MSME owners spread across three sub-districts in the Madiun city area (Kartoharjo, Manguharjo, and Taman) and two sub-districts located in the Madiun Regency (Wungu and Kare) areas. The second phase of research was conducted in early November 2021 by taking the research area in Magetan Regency with the population of food and beverage MSE owners spread across several sub-districts. The sampling technique used in this study is non-probability sampling with the purposive sampling method. Purposive sampling is a sampling technique based on certain considerations. Because the population is not known with certainty, the sample was taken using the purposive sampling technique, determining the model based on specific considerations (Sugiyono 2010), namely: the minimum length of time the business has been running and using information technology applications and Internet networks to access sites (computers, laptops, and smartphones). Therefore, it requires the ability to use IT applications connected to the internet network to facilitate online data collection. The sample target was 300 owners of MSEs in food and beverage. Data collection was done by distributing questionnaires. The distributed questionnaires were tested for validity and reliability levels and distributed online with the Google Form application through social media and offline, namely, visiting the business directly at its location. The validity test uses the criteria if the calculated $r$ value $>r$ table is positive, then the measurement item is declared valid, while the reliability test is seen from the Cronbach's alpha value. The research method uses descriptive statistical analysis statistical testing, processed with the Lisrel program version 8.70 and IBM SPSS Statistic 22. 


\subsection{Measurement}

Referring to Bandura (1977) and Luthans (2011), entrepreneurial self-efficacy (ESE) is operationally defined as the self-confidence possessed by individuals in their ability to succeed in carrying out specific roles in entrepreneurship as seen from the dimensions: individual beliefs, action, and cognitive resources.

Referring to Huarng et al. (2012), entrepreneurial motivational (ME) is operationally defined as a condition from within the individual (internal) that encourages individuals to consciously carry out activities to achieve the desired goal in business. EM measurement refers to Kisker (2016) and Machmud (2017), which includes the following aspects: financial motivation, social motivation, service motivation, self-fulfillment, or achievement motivation.

Business success (BS) is operationally defined as an individual's perceived success in achieving business goals that are owned or run. The measure of business success in business research is the company's financial performance (Chittithaworn et al. 2011). BS measurement indicators refer to Nunes et al. (2012) and Oyeku et al. (2020), which include the following aspects: sales volume, production result, operating profit, business growth, and business development.

Variable measurement scales use Likert scales: 1 (highly disagree), 2 (disagree), 3 (Neutral), 4 (agree), and 5 (highly agree). Research variable measurement items can be seen in Appendix A.

\subsection{The Theoretical Framework}

Based on empirical studies, the business success of an entrepreneur is influenced by various factors, including entrepreneurial self-efficacy (ESE) and entrepreneurial motivational (EM) elements. It is also found that there is a mediating role of EM in the influence of ESE on business success (BS). This is illustrated in the following research model (Figure 1).

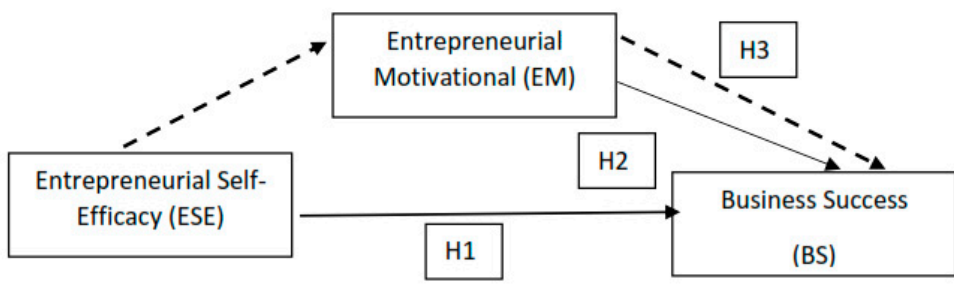

Research Model (Partial Test)

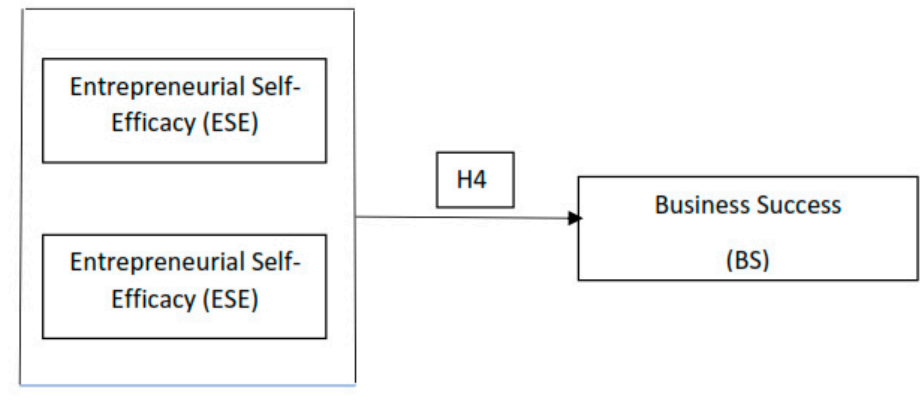

Research Model (Simultaneous Test)

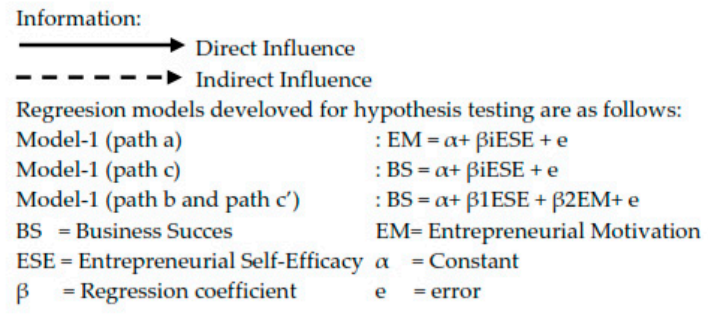

Figure 1. Research Model. 


\section{Results and Discussion}

\subsection{Descriptive of Variables}

Based on the data collection results of 300 questionnaires distributed via Google Form (150 questionnaires) and direct distribution (150 questionnaires), 267 food and beverage MSE actors were willing to respond to questionnaires distributed through social media and offline (response rate: 89\%). The data collection was carried out through two stages: stage (1) January to February 2020, and stage (2) October to November 2021. The results of the validity test obtained $r$ count of all measurement items $>$ r table $(0.1654)$ and Cronbach's alpha value $>0.60$ (Table 2) so that the entire measurement instrument can be used in further analysis.

Table 2. Reliability Test.

\begin{tabular}{cccc}
\hline Variable & Cronbach's Alpha & Critical Values & Criterion \\
\hline Business succes (BS) & 0.844 & 0.60 & Reliable \\
\hline Entrepreneurial self efficacy (ESE) & 0.856 & 0.60 & Reliable \\
\hline Entrepreneurial motivational (EM) & 0.626 & 0.60 & Reliable \\
\hline Business succes (BS) & 0.844 & 0.60 & Reliable \\
\hline
\end{tabular}

Table 2 presents the characteristics of MSE owners who became respondents based on: gender, age, length of business, and business field.

Table 3 shows that $26.12 \%$ of respondents are female and $73.88 \%$ are male; $31.83 \%$ aged $17-26$ years, $28.46 \%$ aged $27-38$ years, $18.73 \%$ aged $37-46$ years, $13.48 \%$ aged $47-56$ years, and $7.50 \%$ aged $>56$ years. When viewed from the length of business, the maximum $(56.18 \%)$ is $1-10$ years. As many as $80.52 \%$ of respondents are business actors in the food sector and $19.48 \%$ in the beverage sector. Food products offered by respondents are generally in the form of typical foods in the business area of operation, such as sambal pecel and nasi pecel, tempeh, meatballs, chicken geprek, gado-gado, chicken noodles, tofu lontong, fried rice, jotos rice, satay, rawon rice, gethuk, cake, various chips, and others. Examples of beverage products offered by respondents are ginger milk, traditional herbs, honey tea, soy juice, and wedang uwuh.

Table 3. Characteristics of Respondents.

\begin{tabular}{ccc}
\hline Gender & Amount & Percentage \\
\hline Man & 70 & $26.12 \%$ \\
Woman & 197 & $73.88 \%$ \\
Total & 267 & $100 \%$ \\
\hline Age & Amount & Percentage \\
\hline 17-26 Years & 85 & $31.83 \%$ \\
27-36 Years & 76 & $28.46 \%$ \\
37-46 Years & 50 & $18.73 \%$ \\
47-56 Years & 36 & $13.48 \%$ \\
>56 Years & 20 & $7.50 \%$ \\
Total & 267 & $100 \%$ \\
\hline Business Length & Amount & Percentage \\
\hline $1-10$ Years & 150 & $56.18 \%$ \\
11-20 Years & 77 & $28.84 \%$ \\
31-40 Years & 30 & $11.24 \%$ \\
$41-50$ Years & 5 & $1.87 \%$ \\
Total & 5 & $1.87 \%$ \\
\hline
\end{tabular}


Table 3. Cont.

\begin{tabular}{ccc}
\hline Gender & Amount & Percentage \\
\hline Business field & Amount & Percentage \\
\hline Food & 215 & $80.52 \%$ \\
Beverage & 52 & $19.48 \%$ \\
Total & 267 & 100 \\
\hline
\end{tabular}

Source: Authors' calculation.

Data analysis was presented using a Likert scale with a minimum value of 1 and a maximum value of 5, after which the average respondent's answer was calculated. The interpretation of the average high and low average of respondents' answers to the studied variables is based on the 0.8 scale range of the research instrument, namely, scale 5 (Table 4 ).

Table 4. Range Scale.

\begin{tabular}{ccc}
\hline Range Scale & Information & Information \\
\hline $1-1.8$ & Highly disagree & Very low \\
$>1.8-2.6$ & Disagree & Low \\
$>2.6-3.4$ & Neutral/moderate & Moderate \\
$>3.4-4.2$ & Agree & High \\
$>4.2-5.0$ & Highly agree & Very high \\
\hline
\end{tabular}

In Table 5, the average value of respondents' responses to the indicators of the variables studied are presented.

Table 5. Description of Research Variables.

\begin{tabular}{ccc}
\hline Variable & Average & Information \\
\hline 1. Entrepreneurial self-efficacy & 4.180 & High \\
\hline Individual beliefs & 4.307 & Very high \\
Action & 4.040 & High \\
Cognitive resources & 4.206 & High \\
\hline 2. Entrepreneurial motivational & 4.132 & High \\
\hline Financial reasons & 4.217 & Very high \\
Social reasons (Social recognition) & 4.047 & High \\
Service reasons & 4.125 & High \\
Self-fulfillment reasons & 4.155 & High \\
(Achievement motivation) & & High \\
\hline 3. Business success & 4.061 & High \\
Sales number & 4.174 & High \\
Production results & 4.110 & High \\
Operating profit & 4.178 & High \\
Business growth & 4.097 & High \\
\hline Business development & 3.933 &
\end{tabular}

Source: Authors' calculation.

In Table 5, it is shown that the entrepreneurial self-efficacy indicator that stands out for food and beverage MSEs in Madiun city, Madiun Regency, and Magetan Regency who are respondents lies in the aspect of the individual belief (4.307), namely, the element of selfconfidence that entrepreneurs can overcome problems in the business they run, can develop their business, believe in profit, and are able to compete. The belief of F\&B business owners in the research area to stay afloat in the pandemic period can be seen from the average value of the "individual beliefs" dimension. Table 5 shows that the action dimensions in ESE have the smallest value of the other two dimensions (4.047). Table 5 shows that the action dimensions in ESE have the smallest value of the other two dimensions. Based on 
the results of interviews with several respondents who are just starting a business, there are still some young entrepreneurs in the field of F\&B who need to increase confidence in their abilities. Some still rely on others, do not believe in products made by themselves, and there are even actors who have not been able to make their own decisions because they still defer to others in running their business.

The most prominent (4.217) is the financial aspect of entrepreneurial motivation. The strongest motivation of micro and small entrepreneurs in the field of food and beverage in the research area in running a business is to earn income to improve the family economy and raise capital for business development. Another factor that motivates the entrepreneur in running a business is self-fulfillment or self-advancement through business ownership, work-life balance, and not being dependent on the family business. Another reason is that such businesses and their services can generate jobs, meet market demand, and get social recognition (i.e., social reasons).

Online business in Indonesia is an increasing trend and conventional offline businesses can participate by adding business content and directions online to survive. The culinary industry is one of the fields of creative business that is on the rise and growing rapidly today with increasing opportunities. In fact, many people, including millennials, are now trying culinary business, both offline and online. In addition to large profits, reaching more than 50 percent, the culinary business has also never died. During the work from home policy launched by the Indonesian government during the COVID-19 pandemic, many culinary businesses started to offer online sales, including online food delivery because many people choose to order food or drinks through online food delivery services such as "gojek and grab", as well as other services from their own business actors while still adhering to health protocols during the pandemic (Cahya 2021). Most prominently, the respondents' business success is the aspect of operating profit (4.178), namely, an increase in operating income every year and an increase in using income during certain events. In contrast, the aspect of business success that is felt the least is business development (3.933). This is possible because if judging from the length of business, most respondents (56.18\%) have a length of trade between 1-10 years. Development of a company is determined by many factors, such as capital, markets, customers, and others that cannot be achieved instantaneously, rather, they require a process. A business process requires persistence, motivation, and resources to grow the business in the future.

\subsection{Hypotheses Testing}

The results of hypothesis testing with path analysis using Lisrel 8.70 can be seen in Table 6. In contrast, the evaluation of the effects of model testing can be seen in Table 6 .

Table 6. Evaluation of Goodness of Fit Kriteria Criteria.

\begin{tabular}{cccc}
\hline Criteria & Result & Critical Values $^{*}$ & Model Evaluation $^{\text {C }}$ \\
\hline Cmin/DF & 2.480 & $1<$ Cmin/DF $<5.00$ & Good \\
Probability & 0.250 & $\geq 0.05$ & Good \\
RMSEA & 0.064 & $\leq 0.08$ & Good \\
GFI & 0.890 & $>0.90$ & Moderate \\
CFI & 0.960 & $\geq 0.94$ & Good \\
\hline
\end{tabular}

Source: * Hair et al. (2010).

Table 6 shows the evaluation of model testing results with good results; only one criterion (GFI) presented moderate results.

Table 7 shows that the effect of entrepreneurial self-efficacy (ESE) on business success (BS) is positive and significant at $18 \%$ with $t$ count $2.981>t$ Table 1.645 (model 1), so H1 is accepted. Likewise, entrepreneurial motivational (EM) influence on business success is positive and significant at $13.3 \%$ with $t$ count $2.186>t$ Table 1.645 (model 2), so H2 is received. The role of entrepreneurial motivation mediation on the impact of self-efficacy entrepreneurship on business success is evident (H3 is received). This is seen from the significant effect of ESE on EM (path a) and the effect of EM on BS is also significant (path 
b). The influence of ESE on BS, both direct influence (path c) and ESE influence on BS after EM control, remains significant (path c'). Referring to Baron and Kenny (1986) about testing the role of mediating variables, this suggests the role of EM is partially mediating over the influence of ESE on BS.

Table 7. Path Coefficient (Standardized Regression) between Variables.

\begin{tabular}{cccccc}
\hline \multirow{2}{*}{ Path } & $\begin{array}{c}\text { Path } \\
\text { Coefficient }\end{array}$ & t Count & t Table & Probability (p) & Information \\
\hline \multicolumn{5}{c}{ Model-1 (path a): EM $=3.773+0.133 E S E$} \\
\hline ESE $\rightarrow$ EM & 0.133 & 2.186 & 1.645 & 0.015 & Significant \\
\hline \multicolumn{5}{c}{ Model-2 (path c) BS $=3.287+0.180 E S E$} \\
\hline ESE $\rightarrow$ BS $\rightarrow$ BS & 0.180 & 2.981 & 0.001 & Significant \\
\hline EM $\rightarrow$ BS & 0.161 & 2.665 & 1.645 & 0.090 & Significant \\
\hline Source: Authors' calculation. & 0.143 & 2.372 & 1.645 & 0.004 & Significant \\
\hline
\end{tabular}

R square of $0.45 \%$ or $45 \%$ in Table 8 shows how much the percentage of entrepreneurial self-efficacy and entrepreneurial motivation affects business success, while other factors outside this study influence the remaining 55\%. F calculates the influence simultaneously at 7.335 with a $p$-value of $0.001<0.050$, meaning H4 is accepted, meaning that simultaneously, both free variables significantly affect the bound variable.

Table 8. R Square and F Calculation.

\begin{tabular}{ccc}
\hline Variable & R Square & F Count \\
\hline Model 3: BS $=2.411+0.161 \mathrm{ESE}+0.143 \mathrm{EM}$ & 0.45 & $\begin{array}{c}7.335 \\
p \text { value: } 0.001\end{array}$ \\
\hline
\end{tabular}

Source: Authors' calculation.

\section{Discussion}

\subsection{Effect of Entrepreneurial Self-Efficacy on Business Success}

With a high level of self-efficacy, business actors can be more confident in achieving business success. A high ESE indicates that business actors believe that they can carry out their duties and become successful entrepreneurs, which is an important aspect in encouraging business success, seen from the number of sales, production results, business profits, business growth, and development. The test results show that the self-efficacy of food and beverage MSEs in Madiun and Magetan has a significant positive effect on the success of their business. This means that the higher the entrepreneurial self-efficacy, the higher the business's success. When viewed from the age of the respondents, most of them are between 17-26 years old (Table 3); the age range is young and are of the $Y$ and millennial generations who are given many conveniences because of digital technology, making it easy to get information quickly, and the mindset and character of students. This type of young entrepreneur is full of ideas and innovation, and has confidence in running the business they started, so the opportunity to achieve business success is enormous. For example, during the COVID-19 pandemic, with the limited time that people have to prepare food, a healthy food menu is a business opportunity to provide healthy food and herbal drinks typical of Indonesia. Based on the results of interviews with several respondents, in order to continue to exist and maintain customers, business owners have made food additions and new menus, with items such as ginger juice drinks, ginger herbs, soy juice, pudding, honey tea, and "wedang uwuh" (https: / / www.detik.com/edu/detikpedia/d-5614929/ accessed on 30 October 2021). The pricing of such new menu items is affordable by 
most Indonesian people. Business owners are utilizing marketing services on online transportation applications for marketing new menus during the pandemic.

This supports Gibson et al. (2012), who state that learning makes a person develop knowledge, skills, and positive behavior and generate creative power by creating new processes in business. The findings in the field show that the most prominent aspect of the ESE is individual beliefs, followed by cognitive resources and action (Table 4). Zaini et al. (2016) mentioned increasing entrepreneurial intentions through unique mental and emotional processes. This becomes a strong predictor of one's actions to start a new business (Bernardus et al. 2020) which ultimately affects the growth and performance of SMEs (Lampadarios 2017; and Machmud 2017) because a person's self-efficacy affects the course of action to be chosen, such as trying to be persistent and tenacious, so that the business carried out is successful.

This finding supports the theory of planned behavior (TPB) that perceived behavioral control is an individual's belief that it will be easy or difficult to perform certain behaviors associated with self-efficacy. High self-efficacy can increase self-confidence in that the individual is capable of certain behaviors, including task roles in entrepreneurship. This means that the higher the self-efficacy of business actors, the higher the business success that can be achieved. The results of this study are in line with Ngek (2015); Dessyana and Riyanti (2017); Adolfina and Lumintang (2018); Budiman and Pangestu (2018); Yusuff et al. (2019); Oyeku et al. (2020); Islam et al. (2020); and Khalil et al. (2021) which show that self-efficacy positively and significantly affect business success because according to Chen et al. (1998), entrepreneurs who have high self-efficacy achieve more innovation and dare to take risks in entrepreneurial tasks.

\subsection{The Influence of Entrepreneurial Motivation on Business Success}

The study results prove that entrepreneurial motivation positively impacts food and beverage MSEs in Madiun City, Madiun Regency, and Magetan Regency (Table 7). High entrepreneurial motivation enables business actors to overcome difficulties they face. Motivation is considered an important factor in entrepreneurship because high motivation in a person can cause, channel, and support a person's behavior so that they want to work hard and enthusiastically achieve optimal results. The most prominent aspect of business success by F\&B business people who are respondents to research is the acquisition of business profits, while aspects of business development need to be improved (Table 6). Entrepreneurial motivation in this empirical study is seen from financial, social, service, and self-fulfillment motives, and the dominant basis compared with others is the financial aspect and self-fulfillment aspect (Table 5); this supports Chittithaworn et al. (2011) and Machmud (2017). Motivation moves entrepreneurs to display behavior towards achieving specific goals, such as business growth. According to Sirec and Mocnik (2010) and Neneh and Vanzyl (2014), measuring MSEs' growth can be seen from employee growth, sales growth, and asset growth. Because the concept of entrepreneurship does not stop when a business is created but also includes the intention to develop the industry, this is following the theory of planned behavior (TPB), that motivation is associated with subjective norms, namely, the individual's view of things that can affect individual interest in taking action. In contrast, motivation is the impetus to take action. This means that entrepreneurial motivation positively affects individual intentions to take action so that their business develops and succeeds. High motivation in entrepreneurship affects a person's success in doing business.

The results indicate that entrepreneurship motivates people to succeed in business profits, independence, and opportunities to develop businesses and create jobs and community recognition. An entrepreneur needs this motivation to grow the intention to work hard and achieve business success. Someone with a solid entrepreneurial basis will use and mobilize all their potential to succeed in entrepreneurship (Nuryanto et al. 2019). The results of the study are in line with Muthalib and Yulianti (2015); Gemina et al. (2016); Kisker (2016); Machmud (2017); and Budiman and Pangestu (2018), which prove that 
motivation affects business performance and business success. Business success is seen in production results, profits, growth, and business development. A growing business can be measured quantitatively, such as increased sales, profits, asset value, and volume of work.

\subsection{Indirect Effect of ESE on BS with EM as a Mediator}

The new findings in the new study compared with previous research lie in the results of an analysis path showing that entrepreneurial motivation (EM) acts as an indirect influence of partial mediation of self-efficacy (ESE) entrepreneurship on business success (BS). This means that high ESE can be decisive either directly or indirectly in influencing business success through EM as mediation. This means that high ESE can be a determinant either directly or indirectly in influencing business success through EM as a mediation. The results of this study reinforce the research of Kristiadi et al. (2016), who find that reason acts as an influence of self-efficacy mediation on entrepreneurial intentions. The results of this study strengthen the research of Eliyana et al. (2020), which found that self-efficacy has an indirect impact on entrepreneurial intentions with entrepreneurial achievement as mediation. Entrepreneurial achievement in the current study is one of the indicators of entrepreneurial motivation measurement. In the study of Pihie and Bagheri (2013), the direct impact of self-efficacy on entrepreneurial intention and the indirect effect of self-efficacy on the entrepreneurial intention with self-regulation as partial mediation are shown, while the results of this study indicate that the influence of entrepreneurial self-efficacy on entrepreneurs has a direct impact on the business success achieved so far. Another study (Norena-Chavez and Guevara 2020) shows a significant complementary mediating effect of entrepreneurial passion on the relationship between entrepreneurial self-efficacy and innovative behavior.

\subsection{Simultaneous Influence of ESE and EM on Business Success}

To become a successful entrepreneur, it is necessary to have the self-confidence to complete the task well, balanced with a strong entrepreneurial motivation. The test results show that ESE and EM simultaneously affect the business success of food and beverage business actors in Madiun (Table 6). This means that to improve the business performance of food and beverage MSEs in Madiun City, Madiun Regency, and Magetan Regency, it is strongly influenced by these business actors' self-efficacy and self-motivation factors. This shows that improved business performance can increase self-efficacy and motivation, such as financial, social, service, and self-fulfillment or achievement. ESE is an individual's belief in a series of necessary actions that can provide an excellent opportunity to achieve the desired level of business performance. Entrepreneurial motivation is needed to achieve actual business performance, consisting of many motives that drive entrepreneurs to achieve it.

\section{Conclusions}

The results of this study reinforce Santoso and Oetomo (2018), which shows that ESE and EM can influence entrepreneurial intentions in achieving business success, as research shows that ESE and EM influence significant and positive business success. This is evident from the results of testing on food and beverage MSEs in Madiun City Madiun Regency, and Magetan Regency, which found a positive and significant effect on business success, either partially or simultaneously. These findings confirm the importance of entrepreneurs' psychological resources in the form of self-efficacy and motivation for the success of food and beverage MSMEs in East Java, Indonesia. This means that entrepreneurial self-efficacy and entrepreneurial motivation have an essential role in increasing the success of entrepreneurs' businesses. This indicates that business owners with high ESE tend to set challenging growth expectations for their company and stay in their quest to achieve those goals. This positively impacts business development and the entrepreneurial work environment and can create a willingness to create business ideas and face business challenges. F\&B business owners who can develop the motivation to achieve and high willingness to dare to take 
risks in connection with opportunities can increase the ability of start-ups and innovate in producing new products; therefore, improving the performance of the business carried out. The indirect impact of entrepreneurial self-efficacy on business success through entrepreneurial motivation is supported. This means that high ESE can be a determinant that can influence business success either directly or indirectly through entrepreneurial motivation.

\subsection{Theoretical Contribution}

The main contribution of this research is to increase understanding for academics on how to understand the impact of the two internal entrepreneurial factors of self-efficacy and motivation contributing to business actors' success. The current study goes forward with two important implications for social cognitive theory (SCT), theory of planned behavior (TPB), and the goal-setting theory.

Research indicates that people with high self-efficacy are confident in surviving and achieving their goals. The results showed that ESE significantly positively influenced business success. This finding supports the SCT initiated by Bandura (1977), which explains that how individuals behave depends on reciprocation between the environment and individual personal factors, especially cognitive factors related to one's belief that they are able or unable to act to achieve certain results successfully (self-efficacy).

The level of entrepreneurial motivation affects a person's business success. Evidence suggests that entrepreneurs are driven by a combination of entrepreneurial motivations such as financial, social, service, and self-fulfillment reasons to start and run a business that increases their capacity to be successful in relation to profitability and growth. These findings support the goal-setting theory that if some people perform better than others despite being equal in ability and knowledge, then the cause should be motivation (Latham and Locke 1991). The findings also support the planned behavior theory put forward by Ajzen (1991) by assuming interest as a motivating factor influencing a behavior, which is indicated by how hard individuals attempt to perform the behavior.

\subsection{Implications for Practice}

Before the pandemic, food and beverage businesses in various regions of Indonesia grew rapidly. Since the spread of COVID-19 in November 2019, companies, including MSEs in the food sector, have tried hard to manage their business and sustain this crisis to avoid closure. Therefore, based on the results of this study, it is recommended that MSE entrepreneurs' ESE needs to be maintained and improved because it can help entrepreneurs energize the need to work hard with a special focus on their goals, thus maintaining their business performance even during the current pandemic. The study recommends that MSE owners should have high confidence in themselves and their ability to steer their businesses resiliently during difficult times such as the COVID-19 pandemic. Most businesses in the F\&B sector during the COVID-19 pandemic experienced a decrease in sales turnover and experienced various marketing and sales constraints and product distribution. Businesses need to continue to find marketing and sales alternatives, secure capital and assets, temporarily divert to other businesses, and learn effective technologies to promote and sell creatively and innovatively.

Culinary MSMEs today must be good at finding market needs that are in accordance with the conditions. Currently, the community is very concerned with health, so MSMEs must be able to create good food and drinks while having good nutritional content. Another innovation that can be considered is to make food in packaging tailored to current needs with attractive design. Someone will be interested in buying culinary products if the packaging is attractive, especially in the digital era where buyers see more products through e-commerce or online motorcycle/taxi food delivery applications. Presently, culinary Indonesia has become an important part of people's lifestyle, and almost everyone loves various types of F\&B. However, to run a culinary business, innovation is needed that 
distinguishes a business from competitors. These innovations can cover skills, shapes, tastes, and presentation creations.

Based on the results of testing and identification of respondent profiles, the majority of MSEs are owned by young people with less than ten years of business experience. Therefore, to improve the performance of MSEs in Indonesia, especially in East Java, in addition to providing marketing facilitation, it is also necessary to pay attention to involvement of the government in providing various business strengthening and mental entrepreneurial development and organizational leadership initiatives to young entrepreneurs. Such initiatives can assist MSE owners in becoming more creative and innovative in running and developing a business, improving the possibility of achieving a successful, longlived business in the competitive global market. Business owners are also expected to follow entrepreneurship activities more often and build good relationships with other entrepreneurs to gain new experiences and obtain various useful information for the business being run.

In Indonesia, MSEs are one of the fields of business with a fairly important role in economic growth and MSEs also have a hand in the absorption of labor and the distribution of results building. In addition to the internal factors of entrepreneurship that need to be improved for the resilience of MSEs during the COVID-19 pandemic, policies from the government are needed in easing the burden of MSEs, including employee protection and information accuracy, improving the economy, income, and employment support for MSMEs, planning, and building resilience capabilities and positive social relationships. In order for MSEs to survive this pandemic, the government is expected to continue to work to overcome the difficulties they experience by providing a number of stimuli for MSEs through loan restructuring policies, additional capital assistance, electricity bill repayment waivers, and other financing support.

\subsection{Limitations and Future Research}

First, research was conducted on food and beverage MSMEs in Madiun City, Madiun Regency, and Magetan Regency, East Java, Indonesia, thus, limiting the conclusion of causation, so that the results of this study cannot be generalized to all types of MSMEs in Indonesia. Future research can expand the research area and other types of creative industry businesses. Second, determining the success of the businesses studied in this study are two internal factors of self-efficacy and entrepreneurial motivation so that further research can explore other internal factors that influence business success: entrepreneurial leadership and innovative work behavior.

Author Contributions: Conceptualization, V.A.S. and Y.B.H.; Methodology: V.A.S. and Y.B.H.; Data curation, V.A.S.; Formal analysis: V.A.S. and Y.B.H.; Validation, V.A.S.; Writing-original draft, V.A.S. and Y.B.H.; Writing-review \& editing, V.A.S. and Y.B.H. All authors have read and agreed to the published version of the manuscript.

Funding: This research received no external funding.

Institutional Review Board Statement: Not applicable.

Informed Consent Statement: Not applicable.

Data Availability Statement: All the data have been included in the manuscript.

Acknowledgments: We want to thank the owners of the food and beverage MSEs and the managers of MD Online Market Madiun who helped non-financially in this research.

Conflicts of Interest: The authors declare no conflict of interest. 


\section{Appendix A. Research Questionnaire}

\section{A Business Success}

\begin{tabular}{ll}
\hline No & Statement \\
\hline 1 & The number of sales of my business (in the last three years) is increasing every year. \\
\hline 2 & My business sales increase during certain events (exhibitions / festivals). \\
\hline 4 & The number of my business production continues to increase (in the last three years) \\
\hline 5 & The number of my business products can meet market demand. \\
\hline 7 & My business income increases for every specific event (exhibition/festival). \\
\hline 8 & In general, my operating income (in the last three years) is increasing every year. \\
\hline 10 & The number of my customers continues to increase every year (in the last three years). \\
\hline 11 & My customers are from various regions outside my current business area. \\
\hline 12 & Marketing my business products is not only in the area where I currently live. \\
\hline 13 & $\begin{array}{l}\text { I have more than one place of business. } \\
\text { I have opened a branch of business outside my current place of business. }\end{array}$ \\
\hline
\end{tabular}

\section{B Entrepreneurial Self-Efficay}

\begin{tabular}{ll}
\hline No & Statement \\
\hline 1 & I am sure I can solve problems in business \\
\hline 2 & I am sure I can expand my current business \\
\hline 3 & I am sure I will get adequate profit \\
\hline 4 & I can compete with similar entrepreneurs \\
\hline 6 & I can manage my resources well \\
\hline 7 & I can work well \\
\hline 9 & I am tireless in facing challenges \\
\hline 10 & I can motivate employees to keep working hard \\
\hline
\end{tabular}

\section{Entrepreneurial Motivation}

\begin{tabular}{ll}
\hline No & Statement \\
\hline 1 & I can earn every month \\
\hline 2 & I can improve the family's economy \\
\hline 3 & I can use the capital I have to develop a business \\
\hline 4 & I am more appreciated in social circles \\
\hline 5 & This effort makes me want to be known by other people \\
\hline
\end{tabular}




\begin{tabular}{ll}
\hline 6 & I can be a role model for others \\
\hline 7 & I feel more honored than working with other people \\
\hline 8 & I can create a new job \\
\hline 9 & I can meet market demand \\
\hline 10 & I can have my own business \\
\hline 12 & I can still divide my time between business and family instead of working with other people \\
\hline 13 & I can start my own business \\
\hline
\end{tabular}

\section{References}

Adolfina, Merinda Ch Pandowo, and Genita G. Lumintang. 2018. Individual Characteristics as Determinants in Developing Micro and Small Enterprises in Manado, Indonesia. International Journal of Business Management and Economic Research 9: 1174-81. Available online: http:/ /ijbmer.com/docs/volumes/vol9issue1/ijbmer2018090101.pdf (accessed on 10 October 2019).

Ajzen, Icek. 1991. The theory of planned behavior. Organizational Behavior and Human Decision Processes 50: 179-211. [CrossRef]

Amit, Raphael, and Eitan MullerAmit. 1995. "Push" and "pull" entrepreneurship. Journal of Small Business and Entrepreneurship 12: 64-80. [CrossRef]

Ardiyanti, Ayu Dyah, and Zulkarnaen Mora. 2019. Pengaruh Minat Usaha Dan Motivasi Usaha Terhadap Keberhasilan Usaha Wirausaha Muda Di Kota Langsa. Jurnal Samudra Ekonomi Dan Bisnis 10: 168-78. [CrossRef]

Bandura, Albert. 1977. Self-efficacy: Toward a unifying theory of behavioral change. Psychological Review 84: 191. [CrossRef]

Barba-Sánchez, V., and C. Atienza-Sahuquillo. 2012. Entrepreneurial behavior: Impact of motivation factors on decision to create a new venture. Investigaciones Europeas de Direccion y Economia de La Empresa 18: 132-38. [CrossRef]

Baron, Reuben M., and David A. Kenny. 1986. The Moderator-Mediator Variable Distinction in Social Psychological Research: Conceptual, Strategic, and Statistical Considerations. Journal of Personality and Social Psychology 51: 1173-82. [CrossRef]

Bernardus, Denny, Fulgentius Danardana Murwani, Elia Ardyan, Liestya Padmawidjaja, Imanuel Deny Krisna Aji, Stefan Yudana Jatiperwira, Djoko Dwi Kusumojanto, Cipto Wardoyo, and Yustinus Budi Hermanto. 2020. Which psychological characteristics strengthen "The entrepreneurial intention-action relationship"?: An extension of the theory of planned behavior. Cogent Business and Management 7: 19. [CrossRef]

Budiman, Ichsan Arief, and Erry R. Pangestu. 2018. Pengaruh motivasi berwirausaha dan efikasi diri terhadap keberhasilan usaha pada Sentra Rajut Binong Jati Bandung. Thesis, Perpustakaan FEB-UNPAS Bandung. Available online: http://repository.unpas.ac $\mathrm{id} / 41157$ (accessed on 10 October 2019).

Cahya, Andika. 2021. Perubahan Bisnis di Masa Pandemi COVID-19. Available online: https:/ /yoursay.suara.com/ (accessed on 30 October 2021).

Caliendo, Marco, Frank Fossen, and Alexander Kritikos. 2010. The impact of risk attitudes on entrepreneurial survival. Journal of Economic Behavior and Organization 76: 45-63. [CrossRef]

Chen, Chao C., Patricia Gene Greene, and Ann Crick. 1998. Does entrepreneurial self-efficacy distinguish entrepreneurs from managers? Journal of Business Venturing 13: 295-316. [CrossRef]

Chittithaworn, Chuthamas, Md. Aminul Islam, Thiyada Keawchana, and Dayang Hasliza Muhd Yusuf. 2011. Factors affecting business success of small \& medium enterprises (SMEs) in Thailand. Asian Social Science 7: 180-90. [CrossRef]

Chu, Hung M., Orhan Kara, Xiaowei Zhu, and Kubilay Gok. 2011. Chinese entrepreneurs Motivations, success factors, problems, and business-related stress. Journal of Chinese Entrepreneurship 3: 84-111. [CrossRef]

David, Fred R., and Forest R. David. 2017. Strategic Management: A Competitive Advantage Approach, Concepts, 16th ed. London: Pearson-Prentice Hall.

Dessyana, Agnes, and Benedicta Prihatin Dwi Riyanti. 2017. The Influence of Innovation and Entrepreneurial Self-Efficacy to Digital Startup Success. International Research Journal of Business Studies 10: 57-68. [CrossRef]

Drnovšek, Mateja, Joakim Wincent, and Melissa S. Cardon. 2010. Entrepreneurial self-efficacy and business start-up: Developing a multi-dimensional definition. International Journal of Entrepreneurial Behaviour E Research 16: 329-48.

Eijdenberg, Emiel L., Leonard J. Paas, and Enno Masurel. 2015. Entrepreneurial motivation and small business growth in Rwanda. Journal of Entrepreneurship in Emerging Economies 7: 212-40. [CrossRef]

Eliyana, Anis, Ahmad Rizki Sridadi Musta'in, and Novia Aviantari. 2020. Linking self efficacy on motivation and entrepreneurial achievements. Systematic Reviews in Pharmacy 11: 328-34. [CrossRef]

Foley, Paul, and Howard Green, eds. 1989. Small Business Success. London: Chapman.

Garaika, Hassan, and Helisia Margahana. 2019. Self efficacy, self personality and self confidence on entrepreneurial intention: Study on young enterprises. Journal of Entrepreneurship Education 22: 1-12.

Gemina, Dwi, Endang Silaningsih, and E. Yuningsih. 2016. Pengaruh Motivasi Usaha terhadap Keberhasilan Usaha dengan Kemampuan Usaha sebagai Variabel Mediasi pada Industri Kecil Menengah Makanan Ringan Priangan Timur-Indonesia. Jurnal Manajemen Teknologi 15: 297-323. [CrossRef] 
Gibson, James L., John M. Ivancevich, James H. Donnely, and Robert Konopaske. 2012. Organizations: Behavior, Structure, Processes, 14th ed. New York: McGraw-Hill/Irwin.

Hair, Joseph, Jr., William C. Black, Barry J. Babin, and dan Rolph F. Anderson. 2010. Multivariate Data Analysis. Irwin: Mc Graw-Hill.

Harianto, Sugeng. 2020. Ini Cara Jitu Pemkot Madiun Kembangkan 23 Ribu UMKM. Available online: https://news.detik.com/beritajawa-timur/d-4908624/ini-cara-jitu-pemkot-madiun-kembangkan-23-ribu-umkm (accessed on 14 October 2021).

Hartman, Evi, and Stefan Herb. 2015. Interconnectedness of actor bonds in service triads-A social capital perspective. Industrial Marketing Management 44: 154-65. [CrossRef]

Huarng, Kun-Huang, Alicia Mas-Tur, and Tiffany Hui-Kuang Yu. 2012. Factors affecting the success of women entrepreneurs. International Entrepreneurship and Management Journal 8: 487-97. [CrossRef]

Islam, Dewan Md Zahurul, Nadeem Khalid, Elmira Rayevac, and Umair Ahmed. 2020. COVID-19 and Financial Performance of SMEs: Examining the Nexus of Entrepreneurial Self-Efficacy, Entrepreneurial Resilience and Innovative Work Behavior. Revista Argentina de Clínica Psicológica 3: 587-93.

Ivancevich, John M., Robert Konopaske, and Michael T. Matteson. 2005. Organizational Behavior and Management, 7th ed. New York: McGraw-Hill/Irwin.

Khalil, Muhammad, Mukaram Ali Khan, Syeb Sohaib Zubair, Hina Saleem, and Syed Nadeem Tahir. 2021. Entrepreneurial self-efficacy and small business performance in Pakistan. Management Science Letters 11: 1715-24. [CrossRef]

Kimathi, Beth Mukiri, Elegwa Mukulu, and Romanus Odhiambo. 2019. Effect of self-Efficacy on the Performance of Small and Medium Enterprises in Kenya. Journal of Entrepreneurship \& Project Management 3: 1-16.

Kisker, Cristhoph Ernest Wilken. 2016. Model For Testing The İmpact Of Motivational Factors of Nascent Entrepreneurs On Business Surviving Success. European Scientific Journal, ESJ 12: 42. [CrossRef]

Kristiadi, Sigit, Ketut Sudarma, and Muhammad Khafid. 2016. Pengaruh sikap berperilaku, norma subjektif dan efikasi diri terhadap intensi kewirausahaan pada siswi melalui motivasi di SMK Negeri 1 Pati. Journal of Economic Education (JEE) 5: 11-21.

Krueger, Norris F., Michael D. Reilly, and Alan L. Carsrud. 2000. Competing models of entrepreneurial intentions. Journal of Business Venturing 15: 411-32. [CrossRef]

Lamanepa, Amelia Wulandari, and Helena Sidharta. 2019. The effect of entrepreneurship education and self-efficacy of entrepreneurial intention. Review of Management and Entrepreneurship 3: 35-45.

Lampadarios, Evripidis. 2017. An Insight into Entrepreurial Success Factors for SMES: The Case of The UK Chemical Distribution Industry. International Journal of Small Business and Entrepreneurship Research 5: 1-20. Available online: www.eajournals.org (accessed on 30 October 2021).

Latham, Gary P., and Edwin A. Locke. 1991. Self-regulation through goal setting. Organizational Behavior and Human Decision Processes 50: 212-47. [CrossRef]

Luthans, Fred. 2011. Advanced Organizational Behavior, 12th ed. New York: McGraw Hill.

Machmud, Senen. 2017. The Effect of Motivational Entrepreneurship on Business Performance of SMEs Moderated by Process Innovation. Archives of Business Research 5: 142-50. [CrossRef]

Martyajuarlinda, Patricia, and Djoko Dwi Kusumajanto. 2018. Effect of Entrepreneurship Education and Self Efficacy Towards the Intention of Entrepreneurship. Jurnal Pendidikan Bisnis Dan Manajemen 4: 142-52. [CrossRef]

McLarty, Roy, Mikulas Pichanic, and Jitka Sarapova. 2012. Factors Influencing the Performance of Small to Medium-Sized Enterprises: An Empirical Study in the Czech Republic. International Journal of Management 29: 36-47.

Muthalib, Abd Azis, and Muh. Nur Yulianti. 2015. The Effect of Entrepreneurial Motivation on Business Performance in the Culinary Industrial Sector. The International Journal Of Engineering And Science (IJES) 4: 23-30.

Neneh, Brownhilder Ngek, and Johan Vanzyl. 2014. Growth Intention and Its Impact on Business Growth amongst Smes in South Africa. Mediterranean Journal of Social Sciences 5: 172-82. [CrossRef]

Ngek, Neneh Brownhilder. 2015. Entrepreneurial self-efficacy and small business performance: The mediating effect of entrepreneurial mindset and openness to experience. Problems and Perspectives in Management 13: 271-80.

Norena-Chavez, Diego, and Ruben Guevara. 2020. Entrepreneurial Passion and Self-Efficacy as Factors Explaining Innovative Behavior: A Mediation Model. International Journal of Economics and Business Administration VIII: 352-73. [CrossRef]

Nuryanto, Uli Wildan, Ratih Purnamasari, Masyhudzulhak Djamil Mz, Ahmad Hidayat Sutawidjaya, and Ahmad Badawi Saluy. 2019. Effect of Self-efficacy, Motivation on Entrepreneurship, Entrepreneurship Education, and Social Environment Againts Interest in Entrepreneurship on Micro, Small and Medium Enterprises Businesses in Serang Regency. Jurnal Akademi Akuntansi 2: 40. [CrossRef]

Nunes, Arcenildo Valderes Da Silva, Eric Dorion, Pelayo Munhoz Olea, Cristine Hermann Nodari, Adrieli Alves Pereira, and E.A. Eliana Andréa Severo. 2012. The use of performance indicators for small and micro enterprises (SMEs): A Brazilian regional experience. African Journal of Business Management 6: 8378-89.

Oetomo, Jonatan A., and Chistina Whidya Utami. 2019. The study of mindset and behavior of businessmen on the theory of the 7 spirit of entrepreneurship. Review of Management and Entrepreneurship 3: 25-34.

Oyeku, Oyedele M., Oduyoye Oluyesi, and Gloria N. 2020. Effect of entrepreneurial orientation, entrepreneurial self-efficacy, and environmental uncertainty on entrepreneurial success. International Journal of Small Business and Entrepreneurship Research 8: 34-67.

Pihie, Zaidatol Akmaliah Lope, and Afsaneh Bagheri. 2013. Self-Efficacy and Entrepreneurial Intention: The Mediation Effect of Self-Regulatio. Vocations and Learning 6: 385-401. [CrossRef] 
Prodan, Igor, and Mateja Drnovsek. 2010. Conceptualizing academic-entrepreneurial intentions: An empirical test. Technovation 30: 332-47. [CrossRef]

Rachmania, Ilma Nurul, Merlyn Rakhmaniar, and Santi Setyaningsih. 2012. Influencing Factors of Entrepreneurial Development in Indonesia. Procedia Economics and Finance 4: 234-43. [CrossRef]

Ramdhani, Muhammad Lutfi. 2021. Perubahan Pola Konsumsi dan Produksi Masyarakat di Masa Pandemi. Available online: https: / / kumparan.com/ (accessed on 30 October 2021).

Republika. 2019. UMKM Punya Peran Penting Bagi Perekonomian Indonesia. Available online: https://www.harianaceh.co.id/2019 /08/06/umkm-punya-peran-penting-bagi-perekonomian-indonesia/ (accessed on 30 October 2021).

Santoso, Singgih, and Budi Sutedjo Dharma Oetomo. 2018. Influence of Motivation and Self-Efficacy on Entrepreneurial Intention to Run a Business. Expert Journal of Marketing 6: 14-21.

Shaheen, Noor, and Shafig AL-Haddad. 2018. Entrepreneurial self-efficacy and entrepreneurial behavior. International Journal of Development and Sustainability 7: 2385-402. Available online: www.isdsnet.com/ijds (accessed on 15 October 2019).

Shakeel, Muhammad, Li Yaokuang, and Ali Gohar. 2020. Identifying the Entrepreneurial Success Factors and the Performance of Women-Owned Businesses in Pakistan: The Moderating Role of National Culture. SAGE Open 10. [CrossRef]

Shane, Scott, Edwin A. Locke, and Christopher J. Collins. 2003. Entrepreneurial motivation. Human Resource Management Review 13: 257-79. [CrossRef]

Simpson, Mike, Joanne Padmore, and Nicki Newman. 2012. Towards a new model of success and performance in SMEs. International Journal of Entrepreneurial Behaviour E Research 18: 264-85. [CrossRef]

Sirec, Kerin, and Dijana Mocnik. 2010. How entrepreneurs' personal characteristics affect SME growth. Our Economy/Nase Gospodarstvo 56: $3-12$.

Sitinjak, Imelda. 2019. The effect of entrepreneurial self-efficacy and entrepreneurial competence on the entrepreneurial entry decision and the success of start-up MSMEs in Medan City. Jurnal Ekonomi Bisnis dan Kewirausahaan (JEBIK) 8: 204-15.

Situmorang, Hendro D. 2021. Bisnis Kuliner UMKM Kemasan Berkembang di Tengah Pandemi. Available online: https://www. beritasatu.com/ (accessed on 30 October 2021).

Sugiyono. 2010. Metode Penelitian Kuantitatif dan Kualitatif dan RED. Bandung: Alfabeta.

Sweida, Gloria L., and Rebecca J. Reichard. 2013. Gender stereotyping effects on entrepreneurial self-efficacy and high-growth entrepreneurial intention. Journal of Small Business and Enterprise Development 20: 296-313. [CrossRef]

Syarizka, Deandra. 2019. Kontribusi UMKM Terhadap PDB 2019 Diproyeksikan Tumbuh 5\%. Available online: https://ekonomi. bisnis.com (accessed on 30 October 2021).

Ummah, Salfiya, and Selvarathnam Gunapalan. 2012. Factors influencing on entrepreneurial success: An empirical studies women headed families in Ampara and Batticaloa Districs in Sri Lanka. International Journal of Business, Economics and Law 1: 141-3148.

Van Praag, C. Mirjam, and Peter H. Versloot. 2008. The economic benefits and costs of entrepreneurship: A review of the research. Foundations and Trends in Entrepreneurship 4: 65-154. [CrossRef]

Wardana, Ludi Wardana, Bagus Shandy Narmaditya, Agus Wibowo, Angga Martha Mahendra, Nyuherno Aris Wibowo, Gleydis Harwida, and Arip Nur Rohman. 2020. The impact of entrepreneurship education and students' entrepreneurial mindset: The mediating role of attitude and self-efficacy. Heliyon 6: e04922. [CrossRef]

Wood, Robert, and Albert Bandura. 1989. Social Cognitive Theory of Organizational Management University of New South Wales. Academy of management Review 14: 361-84. [CrossRef]

Yusuff, Yusrinadini Z., Mahirah Maliani Mohamad, and Nur Yuhainis Ab Wahab. 2019. The Influence of General Self-Efficacy on Women Entrepreneurs. Academy of Entrepreneurship Journal 25: 1-6.

Zaini, Nadzly Zagwan Mohamed, Jati Kasuma Ali, Yusman Yacob, and abduk Ismail Mohd Jawi. 2016. Do Self Efficacy and Familiy Factor Matter? Understanding Women's Entrepreneurial Intention in SMEs in Sarawak. Paper presented at the International Conference on Business and Economics, September 21-23; pp. 1-9. Available online: https://www.europeanproceedings.com/ files/data/article/47/1388/article_47_1388_pdf_100.pdf (accessed on 30 October 2021). 